\title{
Properties of Binding of Partially Purified Glucocorticoid Receptor from Rat Liver with Glucocorticoids of Different Biopotencies
}

\author{
Masao IZAWA, Yukio SATOH, Akio YOSHIDA* And Shogo ICHII \\ Division of Physiology, Institute of Steroid Research and *1st Department of \\ Internal Medicine, Tottori University School of Medicine, Yonago 683
}

\begin{abstract}
To elucidate the relationship between binding parameters and biopotencies of glucocorticoids, we partially purified the receptor from the liver cytosol of rats in a dexamethasone-bound and unactivated form by precipitation with protamine sulfate, gel filtration and DEAE-cellulose chromatography (approximately 100 -fold) and examined the interaction of the preparation with 3 glucocorticoids of different biopotencies (dexamethasone; Dex, corticosterone; Cort and prednisolone; Pred). The partially purified receptor (PPR) was stable at $-20^{\circ} \mathrm{C}$ for a: leas: 2 months in the presence of bovine serum albumin, glycerol, molybdace and dithiothreitol. Treatment of the PPR with p-hyroxymercuribenzoate liberated the ligands and the treated PPR reassociated ${ }^{3} \mathrm{H}-$ glucocorticoids efficiently following the addition of dithiothreitol. The reassociated PPR was bound to the DNA-cellulose after a brief heating. Metabolic activity on ligands and inactivation of the binding sites in the PPR were insignificant under the conditions used. $\mathrm{K}_{\mathrm{d}}$ 's were $\sim 0.9, \sim 3$ and $\sim 6 \mathrm{nM}$ for Dex, Cort and Pred, respectively $\left(\right.$ at $\left.0^{\circ} \mathrm{C}\right)$. Relative binding affinity of ligands to the PPR which was estimated by competitions was higher in the order of triamcinolone acetonide $>$ Dex $>$ Cort $>$ Pred $>$ progesterone $>$ cortexolone. Association of Dex and Cort was relatively rapid and significantly accelerated by raising the incubation temperature, while the association of Pred was slower and effects of the temperature was moderate. The rate of dissociations was also varied with ligands. The rate of dissociation of Dex was the lowest among the 3 ligands and was elevated by raising the temperature. Because the effect of temperature was more pronounced in the dissociation than in the association, apparent $K_{a}$ 's decreased at higher temperature. Thermodynamic examinations of glucocorticoid binding in the PPR revealed that the binding reaction proceeds at a higher rate in the order of Dex $>$ Cort $>$ Pred. Because the relative biopotencies of these 3 glucocorticoids in vivo is higher in the order of Dex> Pred $>$ Cort, from the results obtained in the present study, it appears that biopotency of glucocorticoids in vivo does not correlate with the affinity of the binding to the receptor estimated in vitro.
\end{abstract}

Received January 11, 1985

The following trivial names are used: cortexolone; $17 \alpha$, 21-dihydroxypregna-4-ene-3, 20-dione, corticosterone (Cort); 11 $\beta, 21$-dihydroxypregna-4ene-3, 20-dione, dexamethasone (Dex); 9 9 -fluoro$11 \beta, 17 \alpha, 21$-trihydroxy-16 $\alpha$-methyl-pregna-1, 4diene-3, 20-dione, diethylstilbestrol; 4, 4'-(1, 2- diethyl-1, 2-ethenediyl)-bisphenol, prednisolone (Pred); $11 \beta, 17 \alpha, 21$-trihydroxypregna-1, 4-diene3,20 -dione, progesterone; pregna-4-ene-3, 20dione, testosterone; $17 \beta$-hydroxyandrost-4-ene-3one, triamcinolone acetonide; $9 \alpha$-fluoro-11 $\beta, 16 \alpha$, $17 \alpha, 21$-tetrahydroxypregna-1, 4-diene-3, 20-dione cyclic 16,17 -acetal with acetone. 
A number of investigations on the relationship between steroid structure and biopotency of glucocorticoids have been performed and it has been suggested that the binding affinity of glucocorticoids to the receptor is attributed to one of the factors which determine the biopotency (Baxter and Tomkins, 1971, Jones and Bell, 1982, Lamontagne et al., 1984, Miyabe and Harrison, 1983, Pratt et al., 1975, Rousseau et al., 1972, Samuels and Tomkins, 1970). In a previous study in this laboratory where the nuclear binding ability of glucocorticoids with different biopotencies was compared (Ichii et al., 1983), it was revealed that parameters of binding of glucocorticoids to the receptor were almost entirely unreliable when metabolic transformation of ligands had taken place during the period of incubation. To elucidate the relationship between binding parameters and biopotencies of glucocorticoids, it seemed to be necessary to estimate the rate of the binding in a purified preparation of the receptor.

In the present study, we partially purified the glucocorticoid receptor in the cytosol from rat livers and association and dissociation of the glucocorticoids of different biopotencies were examined under the conditions where the transformation of the ligands was avoided during the period of the incubations. In addition, thermodynamic examination on the formation and degradation of glucocorticoid-receptor complexes was also performed using the partially purified preparations.

\section{Materials and Methods}

\section{Chemicals}

$\left[1,2,4-{ }^{3} \mathrm{H}\right]$ Dexamethasone $\left({ }^{3} \mathrm{H}-\mathrm{Dex}, \quad 42 \mathrm{Ci} /\right.$ mmol), $\left[1 \alpha, \quad 2 \alpha(\mathrm{n})-{ }^{3} \mathrm{H}\right]$ corticosterone $\quad\left({ }^{3} \mathrm{H}\right.$-Cort, $43 \mathrm{Ci} / \mathrm{mmol})$ and $\left[2,4,6,7-{ }^{3} \mathrm{H}\right]$ prednisolone $\left({ }^{3} \mathrm{H}-P r e d, \quad 59 \mathrm{Ci} / \mathrm{mmol}\right)$ were purchased from Amersham Internatl. Ltd. (Amersham, UK). Unlabeled steroids and diethylstilbestrol were obtained from Sigma Chemical Co. (St. Louis, MO, USA). DNA-cellulose was prepared ac- cording to the method of Alberts and Herrick (1971) using calf thymus DNA (Sigma, Type I) and cellulose powder (CF-11, Whatmann, Kent, UK). For chromatography, Sephadex G-25 and G-100 (Pharmacia, Uppsala, Sweden), DEAEcellulose (DE 53, Whatmann) and silica gel powder (GF 254, Merk, Darmstadt, FRG) were used. Other chemicals used were of analytical grade from Nakarai Chemicals Co. (Kyoto, Japan).

\section{Preparation of the partially purified receptor (PPR)}

The livers from male Wistar rats weighing 300-350 g were perfused in situ with isotonic saline via the portal vein. For preparation of the cytosols, the livers were homogenized in 1.5 volumes of ice-cold TEMoDTT buffer solution (T, $15 \mathrm{mM}$ Tris- $\mathrm{HCl}, \mathrm{pH} 7.4$ at $15^{\circ} \mathrm{C}$; E, $0.5 \mathrm{mM}$ EDTA; Mo, $10 \mathrm{mM}$ sodium molybdate and DTT, $10 \mathrm{mM}$ dithiothreitol). The homogenates were centrifuged at $105,000 \times \mathrm{g}$ for $1 \mathrm{~h}$ at $2^{\circ} \mathrm{C}$ and the resultant supernatant was used as the cytosol after removing the lipid layer. The cytosol was incubated with $20 \mathrm{nM}$ of ${ }^{3} \mathrm{H}$-Dex at $0^{\circ} \mathrm{C}$ for 16 $\mathrm{h}$ and purification of the ${ }^{3} \mathrm{H}$-Dex-receptor complex was performed according to the method of Govindan and Sekeris (1978) with minor modifications. Briefly, 0.1 volume of $10 \%$ solution of streptomycin in the TEMoDTT buffer was added slowly to the labeled cytosol, incubated at $0^{\circ} \mathrm{C}$ for $20 \mathrm{~min}$ and centrifuged at $10,000 \times \mathrm{g}$ for $15 \mathrm{~min}$. To the supernatant, 0.08 volumes of $1 \%$ solution of protamine sulfate in the TEMoDTT buffer were added with mixing, incubated at $0^{\circ} \mathrm{C}$ for $15 \mathrm{~min}$ and centrifuged at $10,000 \times \mathrm{g}$ for $15 \mathrm{~min}$. The pelleted material was extracted with small volumes of KPMo buffer $\left(160 \mathrm{mM}\right.$ potassium phosphate, $\mathrm{pH} 7.4$ at $15^{\circ} \mathrm{C}$ and $10 \mathrm{mM} \mathrm{Mo}$ ) at $0^{\circ} \mathrm{C}$ for $15 \mathrm{~min}$ and centrifuged at $50,000 \times \mathrm{g}$ for $20 \mathrm{~min}$. The supernatant was applied to a Sephadex G-100 column $(0.9 \times 50$ $\mathrm{cm}$ ) which has been equilibrated with the KPMo buffer, and the void volume fraction of the column was further applied to a Sephadex G-25 column $(0.9 \times 35 \mathrm{~cm})$ equilibrated with TEMoDTT buffer $\left(\mathrm{pH} 7.85\right.$ at $\left.15^{\circ} \mathrm{C}\right)$. The void volume fraction from the Sephadex G-25 column described above was finally separated on a DEAE-cellulose column (DE 53, $1.2 \times 5 \mathrm{~cm}$ ) which has been equilibrated with the TEMoDTT buffer $(\mathrm{pH}$ 7.85) and eluted with the same buffer supplemented with increasing concentrations of $\mathrm{KCl}$ in a stepwise manner $(0.05,0.1,0.2,0.3,0.4$ and $0.5 \mathrm{M}$ $\mathrm{KCl}$, respectively). Most of the receptor complex 
was recovered in the buffer containing $0.2 \mathrm{M}$ $\mathrm{KCl}$ (Ichii et al., 1983) and stored at $-20^{\circ} \mathrm{C}$ after adding bovine serum albumin (BSA, $15 \mathrm{mg} /$ $\mathrm{ml})$ and glycerol $(30 \%)$ which had been dissolved in the TEMoDTT buffer $(\mathrm{pH} 7.85)$. This preparation was stable at $-20^{\circ} \mathrm{C}$ for at least 2 months without a measurable loss of binding activity. According to these procedures, approximately a 20-fold increase in the concentration of the receptor complex was attained by treatments with streptomycin and protamine sulfate and a further 5-6 fold increase in the concentration of the receptor complex was achieved by the following DEAE-cellulose chromatography. In this manner, approximately 100 -fold purification was achieved (based on per unit of protein) with overall recovery of approximately $30 \%$.

Dissociation from and association to the PPR of ${ }^{3} H$-glucocorticoids

The ${ }^{3} \mathrm{H}$-Dex bound to the PPR was dissociated by the method of Banerji and Kalimi (1981) with minor modifications. Briefly, DTT in the PPR preparation was removed by passing through a Sephadex G-25 column $(0.9 \times 35 \mathrm{~cm})$ equilibrated with the TEMo buffer and the bound ligand was liberated by treating the PPR with $0.8-1.0 \mathrm{mM}$ of p-hydroxymercuribenzoate (PHMB) at $0^{\circ} \mathrm{C}$ for 40-60 min. More than $90 \%$ of the bound ${ }^{3} \mathrm{H}-$ Dex was dissociated from the PPR by this treatment. The PHMB-treated preparation was further applied to a Sephadex G-25 column in the same manner as described above to remove liberated ligands and PHMB, and the void volume fraction was collected. For determination of the rate of reassociation of ${ }^{3} \mathrm{H}$-glucocorticoids or for preparation of ${ }^{3} \mathrm{H}$-glucocorticoid-receptor complex in the PPR, incubations were carried out in the presence of $10 \mathrm{mM}$ DTT at $0^{\circ} \mathrm{C}$ for appropriate time intervals. At the end of the incubation period, 0.25 volume of dextran-coated charcoal (DCC, $0.25 \%$ and $2.5 \%$ in the TE buffer) was added, left at $0^{\circ} \mathrm{C}$ for $15 \mathrm{~min}$ and centrifuged at $3,000 \times$ $\mathrm{g}$ for $5 \mathrm{~min}$ to remove charcoal. To correct non-specific binding, a 1,000-fold molar excess of the respective radioinert steroids was included in the parallel incubations. The non-specific binding of ${ }^{3} \mathrm{H}$-glucocorticoids to the PPR was less than $3 \%$ of the total binding under the experimental conditions described above.

Binding to DNA-cellulose of the ${ }^{3} H$-Dex receptor complex reassociated in the PPR

The ${ }^{3} \mathrm{H}$-Dex receptor complex reassociated in the PPR was prepared by incubating the PHMBtreated PPR with $20 \mathrm{nM}$ of ${ }^{3} \mathrm{H}$-Dex at $0^{\circ} \mathrm{C}$ for $4 \mathrm{~h}$ in the presence of $10 \mathrm{mM}$ Mo and $10 \mathrm{mM}$ DTT. The unbound ligands and Mo were removed by passing through a Sephadex G-25 column $(0.9 \times 35 \mathrm{~cm})$ equilibrated with TEDTT buffer. The void volume fraction was divided into 2 tubes and one was incubated at $20^{\circ} \mathrm{C}$ for $20 \mathrm{~min}$ and the other was left at $0^{\circ} \mathrm{C}$ for the same period. Aliquots of these labeled PPR were incubated with DNA-cellulose ( $40 \mathrm{mg}$ powder containing $150 \mu \mathrm{g}$ DNA) at $0^{\circ} \mathrm{C}$ for $30 \mathrm{~min}$. The radioactivity associated with DNA was estimated by subtracting that associated with the same amount of plain cellulose as described previously (Izawa et al., 1984).

\section{Thin-layer chromatography (TLC) of incubated ligands}

To examine the matabolic transformation of ligand which was found to have a profound effect on the binding parameters of receptors (Ichii et al., 1983), the PPRs incubated with ${ }^{3} \mathrm{H}$ ligands were deproteinized in $80 \%$ ethanol. The ethanol extract was evaporated and the residue was spotted on a TLC plate of silica gel (GF $254,10 \times 20 \mathrm{~cm}$ ) with a small volume of methylene chloride: methanol mixture $(1: 1)$. The plate was developed by the solvent system of chloroform: ethanol mixture $(8: 2)$. After development, $10 \mathrm{~mm}$ fractions of each silica gel sample was scraped off, transferred into a counting vial and the radioactivity of each fraction was determined after extracting the silica gel with $1 \mathrm{ml}$ of ethanol.

\section{Analytical methods}

Protein in the samples was precipitated with ice-cold 5\% trichloroacetic acid (TCA), washed once with the same TCA and determined by the method of Lowry et al. (1951) using BSA as the standard. DNA was determined by the method of Burton (1968) using calf thymus DNA as the standard. Radioactivity was determined in a liquid scintillation spectrometer (ALOKA LSC-700) with automatic external standardization for quenching correction.

\section{Results}

Binding parameters and binding specificity of the PPR

The PPR treated with PHMB as described 
by Banerji and Kalimi (1981) liberated more than $90 \%$ of the bound ${ }^{3} \mathrm{H}$-Dex by the end of the treatment. After removing the liberated ${ }^{3} \mathrm{H}$-Dex and PHMB by Sephadex G-25 chromatography, the PPR could reassociate ${ }^{3} \mathrm{H}$-Dex, ${ }^{3} \mathrm{H}$-Cort and ${ }^{3} \mathrm{H}$-Pred efficiently in the presence of Mo and DTT, and again more than $90 \%$ of the initial binding sites were recovered. Modes of the binding of ${ }^{3} \mathrm{H}$-Dex, ${ }^{3} \mathrm{H}$-Cort and ${ }^{3} \mathrm{H}$-Pred to the PHMB-treated PPR were examined by the method of Scatchard (1949) and were compared with those to the unpurified liver cytosol (Fig. 1). $\mathrm{K}_{\mathrm{d}}$ 's of ${ }^{3} \mathrm{H}$-Dex, ${ }^{3} \mathrm{H}$-Cort and ${ }^{3} \mathrm{H}$-Pred to the PPR were $\sim 0.9, \sim 3$ and $\sim 6 \mathrm{nM}$, respectively, and almost identical numbers of maximum binding sites for these 3 ligands were observed. When an aliquot of the incubation mixtures was removed at the end of the incubations and analyzed by TLC, no changes in the mobility of these 3 glucocorticoids were noticed (Fig. 2). On the other hand, the numbers of maximum binding sites for ${ }^{3} \mathrm{H}$-Cort and ${ }^{3} \mathrm{H}$-Pred in the liver cytosol were considerably lower than that for ${ }^{3} \mathrm{H}$-Dex and this might be attributable to the metabolic transformation of these ligands in the cytosol during the period of incubation (data not shown, also refer Ichii et al., 1983, 1984). The $\mathrm{K}_{\mathrm{d}}$ 's in the cytosol were also different from those in the PPR. Pred exhibited higher affinity than Cort in the cytosol. Steroid specificity examined by the inhibition of ${ }^{3} \mathrm{H}$-Dex binding in the PPR was also compared with that in the liver cytosol (Fig. 3). In the PPR, in addition to the steroids which possess the biopotency of glucocorticoid, progesterone and cortexolone, antiglucocorticoids, inhibited the ${ }^{3} \mathrm{H}$ Dex binding efficiently. The rate of inhibi-

Fig. 1. Scatchard plot of the binding of ${ }^{3} \mathrm{H}-\mathrm{Dex},{ }^{3} \mathrm{H}$-Cort and ${ }^{3} \mathrm{H}-\mathrm{Pred}$ in the liver cytosol and the PPR.

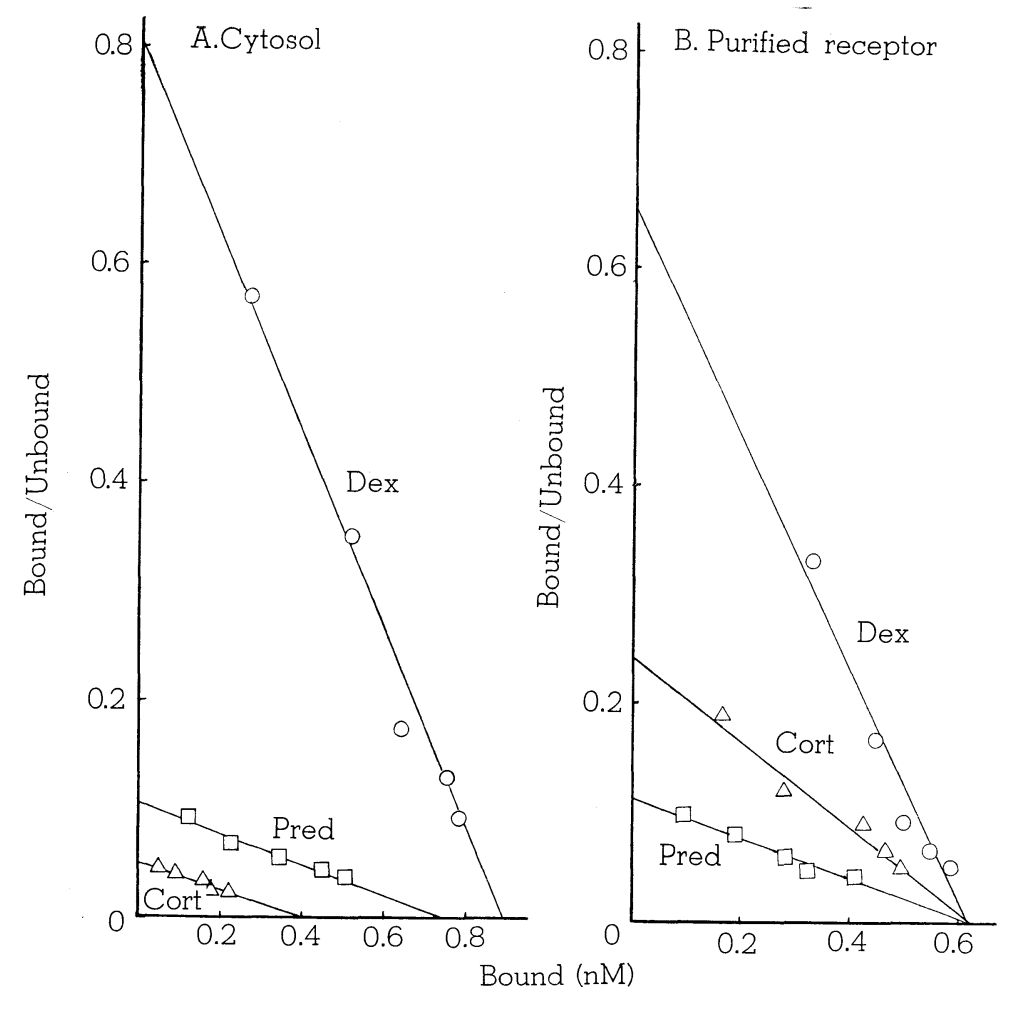

The liver cytosol (Fig. 1A, approximately $0.8 \mathrm{mg}$ as protein per tube) and the unoccupied PPR (Fig. 1-B, approximately $1.5 \mathrm{mg}$ as protein* per tube) were incubated with a series concentration of ${ }^{3} \mathrm{H}$-ligands $(1-10 \mathrm{nM})$ in $0.4 \mathrm{ml}$ of TEMoDTT buffer at $0^{\circ} \mathrm{C}$ for $16 \mathrm{~h}$ and the bound radioactivity was measured as described in 'Materials and Methods.' In parallel incubations, 1,000-fold molar excess of radioinert ligands was added and the radioactivity which was not displaced by the addition of unlabeled ligands was referred to as non-specific binding. $\bigcirc$; ${ }^{3} \mathrm{H}$-Dex, $\triangle$; ${ }^{3} \mathrm{H}-$ Cort, $\square ;{ }^{3} \mathrm{H}$-Pred.

* The PPR was diluted with BSA $(15 \mathrm{mg} / \mathrm{ml})$. Therefore the amount of protein derived from the liver cytosol was approximately $5 \mu \mathrm{g}$ per tube. 

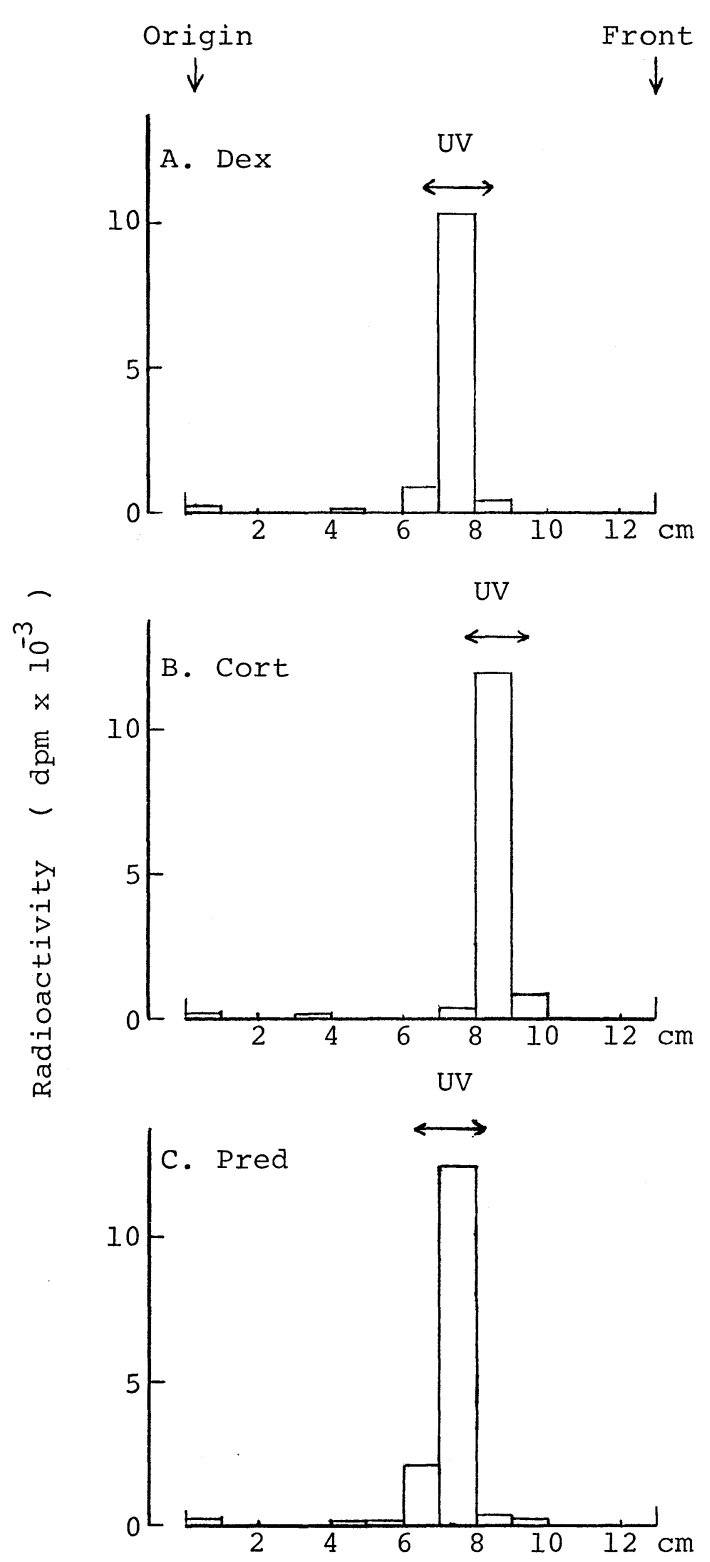

Fig. 2. Thin-layer chromatography of ${ }^{3} \mathrm{H}$-ligands after incubation in the PPR.

The unoccupied PPR (5 $\mathrm{mg}$ per $\mathrm{ml}$ as protein) was incubated with $5 \mathrm{nM}$ of ${ }^{3} \mathrm{H}$-glucocorticoids in the presence of $10 \mathrm{mM}$ DTT at $0^{\circ} \mathrm{C}$ for 16 $\mathrm{h}$. At the end of incubation, an aliquot of the mixture was treated as described in 'Materials and Methods' for TLC. The plate was developed with chloroform: ethanol mixture $(8: 2)$. After development of the TLC-plate, $10 \mathrm{~mm}$ strips of silica gel were scraped off and $\nearrow$ tion was higher in the order of triamcinolone acetonide $>$ Dex $>$ Cort $>$ Pred $>$ progesterone $>$ cortexolone (Fig. 3-B). However, the rate of inhibition by Cort in the liver cytosol was much lower than that observed in the PPR and inhibition by progesterone and cortexolone was not observed in the liver cytosol (Fig. 3-A). The inhibition rate was higher in the order of triamcinolone acetonide $>$ Dex $>$ Pred $>$ Cort in the cytosol.

Binding to DNA-cellulose of the PPR reassociated with ${ }^{3} \mathrm{H}$-Dex

Mo was removed from the PPR reassociated with ${ }^{3} \mathrm{H}$-Dex by passing through a Sephadex G-25 column and the PPR was heated at $20^{\circ} \mathrm{C}$ for $20 \mathrm{~min}$ in the presence of DTT. The heated ${ }^{3} \mathrm{H}$-Dex-PPR complex was incubated with the DNA-cellulose at $0^{\circ} \mathrm{C}$ for another $30 \mathrm{~min}$ and the ${ }^{3} \mathrm{H}$-Dex bound to the DNA-cellulose was examined (Table 1). A significant amount of ${ }^{3} \mathrm{H}$-Dex was bound to the DNA-cellulose, but the PPR reassociated with ${ }^{3} \mathrm{H}$-Dex and unheated or heated without removing Mo did not bind to the DNA-cellulose significantly.

\section{Kinetics of ${ }^{3} H$-glucocorticoid binding in the $P P R$}

Kinetics of association and dissociation of ${ }^{3} \mathrm{H}$-Dex, ${ }^{3} \mathrm{H}$-Cort and ${ }^{3} \mathrm{H}$-Pred with/from the PPR were examined (Figs. 4 and 5). The association of ${ }^{3} \mathrm{H}$-Dex and ${ }^{3} \mathrm{H}$-Cort with the PPR was faster than that of ${ }^{3} \mathrm{H}$-Pred (Fig. 4). The rates of association of ${ }^{3} \mathrm{H}$ Dex and ${ }^{3} \mathrm{H}$-Cort were increased significantly by raising the incubation temperature $(0 \sim$ $20^{\circ} \mathrm{C}$ ), while the effect of temperature on the ${ }^{3} \mathrm{H}$-Pred association was relatively small.

Transferred to a counting vial. One $\mathrm{ml}$ of ethanol was added to each vial and radioactivity was measured. Horizontal arrows denoted as UV in the figure indicate the location of authentic glucocorticoids cochromatographed. 

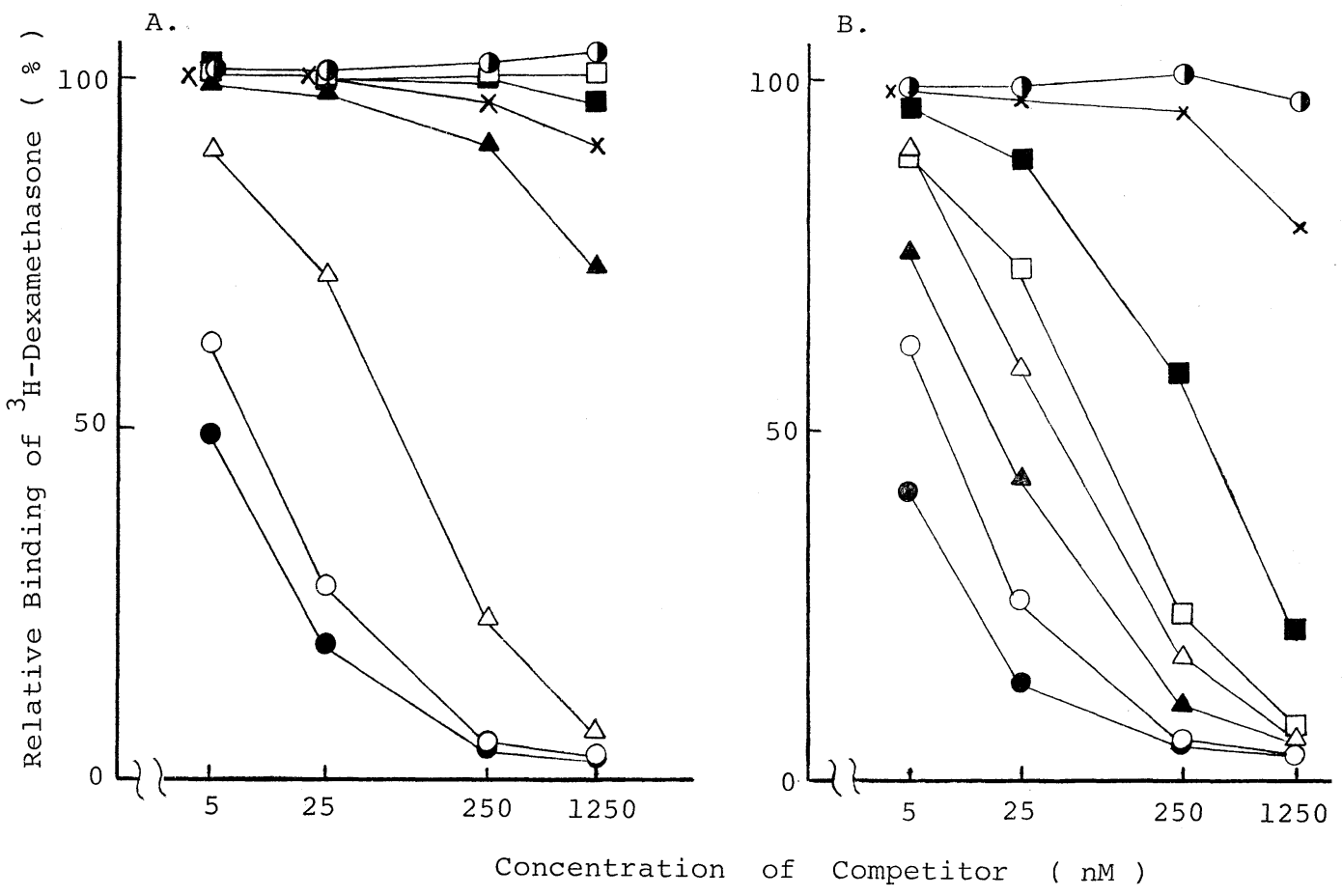

Fig. 3. Steroid specificity of the ${ }^{3} \mathrm{H}$-Dex binding in the liver cytosol and in the PPR.

Aliquots of the liver cytosol (Fig. 3-A, $3.8 \mathrm{mg}$ as protein) and the unoccupied PPR (Fig. $3-\mathrm{B}, 0.75 \mathrm{mg}$ as protein) were incubated with ${ }^{3} \mathrm{H}$-Dex $(5.4 \mathrm{nM})$ at $0^{\circ} \mathrm{C}$ for $16 \mathrm{~h}$ in $0.4 \mathrm{ml}$ of the TEMoDTT buffer. To estimate the inhibitory effect of unlabeled competitors, various concentrations of competitors were added to the incubation mixtures as ethanol solutions. The concentration of ethanol was less than $0.2 \%$ in all instances. Binding in the absence of competitor was $42,500 \mathrm{dpm}$ per tube (cytosol, Fig. 3-A) and $24,000 \mathrm{dpm}$ per tube (PPR, Fig. 3-B), respectively and relative binding of ${ }^{3} \mathrm{H}$-Dex was expressed as a percentage of the binding in the absence of competitor. $\bigcirc$; Triamcinolone acetonide, $\bigcirc$; Dex, $\boldsymbol{\Delta}$; Cort, $\triangle$; Pred, $\square$; Progesterone, $\mathbf{\square}$; Cortexolone, $\times$; Testosterone, Diethylstilbestrol.

Table 1. Binding to DNA-cellulose of the PPR labeled with ${ }^{3} \mathrm{H}$-Dex.

\begin{tabular}{cc}
\hline $\begin{array}{c}\text { Pre-treatment of } \\
{ }^{3} \mathrm{H} \text {-Dex-receptor }\end{array}$ & $\begin{array}{c}\text { Bound } \\
\text { Radioactivity }\end{array}$ \\
\hline $0^{\circ} \mathrm{C}$ for $20 \mathrm{~min}$ & $210 \mathrm{dpm}$ \\
$20^{\circ} \mathrm{C}$ for $20 \mathrm{~min}$ & 3,576 \\
$20^{\circ} \mathrm{C}$ for $20 \mathrm{~min}$ in the presence \\
of $10 \mathrm{mM} \mathrm{Mo}$
\end{tabular}

The PPR labeled with ${ }^{3} \mathrm{H}$-Dex as described in 'Materials and Methods' was prepared and Mo in the PPR preparation was excluded by passing through a Sephadex G-25 column $(1.2 \times 30 \mathrm{~cm})$ equilibrated with the TE buffer supplemented with $10 \mathrm{mM}$ DTT. After treat- $\nearrow$
Iment of the PPR as indicated in the Table, an aliquot of each $(32,148 \mathrm{dpm}, 3.9 \mathrm{mg}$ as protein) was used for the DNA-cellulose binding experiments. The assay mixture $(0.5$ $\mathrm{ml})$ contained $40 \mathrm{mg}$ of DNA-cellulose $(150$ $\mu \mathrm{g}$ as DNA) or the same amount of plain cellulose and was incubated at $0^{\circ} \mathrm{C}$ for $30 \mathrm{~min}$. Bound radioactivity was obtained by subtracting the radioactivity bound to plain cellulose from that bound to DNA-cellulose. For other details of the experimental conditions, see the 'Materials and Methods.' 
At all temperatures examined, the association reactions of the 3 glucocorticoids followed second-order kinetics. On the other hand, the dissociation reaction of ${ }^{3} \mathrm{H}-\mathrm{Dex}$, ${ }^{3} \mathrm{H}$-Cort and ${ }^{3} \mathrm{H}$-Pred from the PPR followed first-order kinetics under the experimental conditions used (Fig. 5). The rate of dissociation of ${ }^{3} \mathrm{H}$-Cort and ${ }^{3} \mathrm{H}$-Pred from the PPR were low at low temperature $\left(\mathrm{t}_{1 / 2}\right.$ at $0^{\circ} \mathrm{C}$ was $3.5 \mathrm{~h}$ in ${ }^{3} \mathrm{H}$-Cort and $2.5 \mathrm{~h}$ in ${ }^{3} \mathrm{H}$-Pred, respectively) but it was elevated markedly by raising the incubation temperature $\left(\mathrm{t}_{1 / 2}\right.$ at $20^{\circ} \mathrm{C}$ was $0.5 \mathrm{~h}$ in ${ }^{3} \mathrm{H}$-Cort and $0.6 \mathrm{~h}$ in ${ }^{3} \mathrm{H}$ Pred, respectively). Among the labeled glucocorticoids examined, ${ }^{3} \mathrm{H}$-Dex dissociated from the PPR most slowly and the $t_{1 / 2}$ was $9.7 \mathrm{~h}$ at $0^{\circ} \mathrm{C}, 5.1 \mathrm{~h}$ at $10^{\circ} \mathrm{C}$ and $1.6 \mathrm{~h}$ at $20^{\circ} \mathrm{C}$. Under these conditions, significant decrease in the binding capacity of the unlabeled PPR and metabolic transformation of ligands were not detected (date not shown). The rate constants of association $\left(\mathrm{k}_{1}\right)$ and dissociation $\left(\mathrm{k}_{2}\right)$ estimated from Figs. 4 and 5 are given in Table 2. The elevation of $\mathrm{k}_{2}$ caused by raising the temperature was more pronounced than the enhancement of $k_{1}$, so that the apparent $\mathrm{K}_{\mathrm{a}}$ was decreased at the higher temperatures.

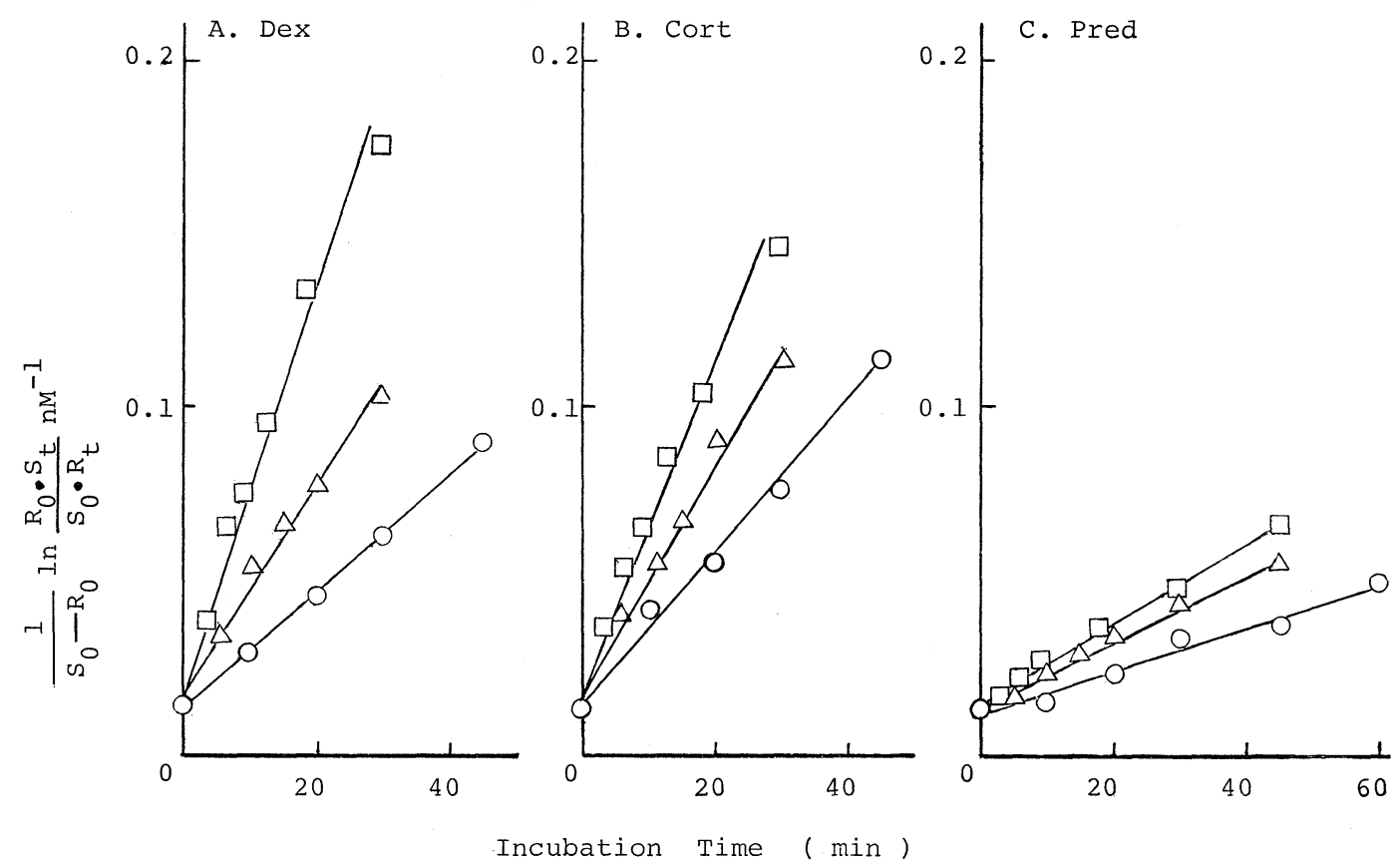

Fig. 4. Effect of temperature on the association kinetics of ${ }^{3} \mathrm{H}$-glucocorticoids in the PPR.

The concentration of the binding sites in the PPR ( $\left.R_{0}\right)$ was $1.33 \mathrm{nM}$ (approximately $4 \mathrm{mg}$ per $\mathrm{ml}$ as protein) and the initial concentration $\left(\mathrm{S}_{0}\right)$ of ${ }^{3} \mathrm{H}$-Dex, ${ }^{3} \mathrm{H}$-Cort and ${ }^{3} \mathrm{H}$-Pred were $7.5,9.2$ and $9.1 \mathrm{nM}$, respectively. The incubation was performed at $0(\bigcirc), 10(\triangle)$ and $20^{\circ} \mathrm{C}$ ( $\square)$. At various time intervals after the addition of ligands, the concentrations of bound ${ }^{3} \mathrm{H}$-glucocorticoids were determined by the DCC procedure and the values obtained were used to calculate the concentration of the unoccupied binding sites $\left(R_{t}\right)$ and free steroids $\left(S_{t}\right)$ at corresponding time (t). Results are expressed as $\frac{1}{S_{0}-R_{0}} \ln \frac{R_{0} \cdot S_{t}}{S_{0} \cdot R_{t}} n^{-1}$ and plotted against incubation time. The rate constant of association $\left(k_{1}\right)$ was calculated from the slopes of the lines in the figure. 

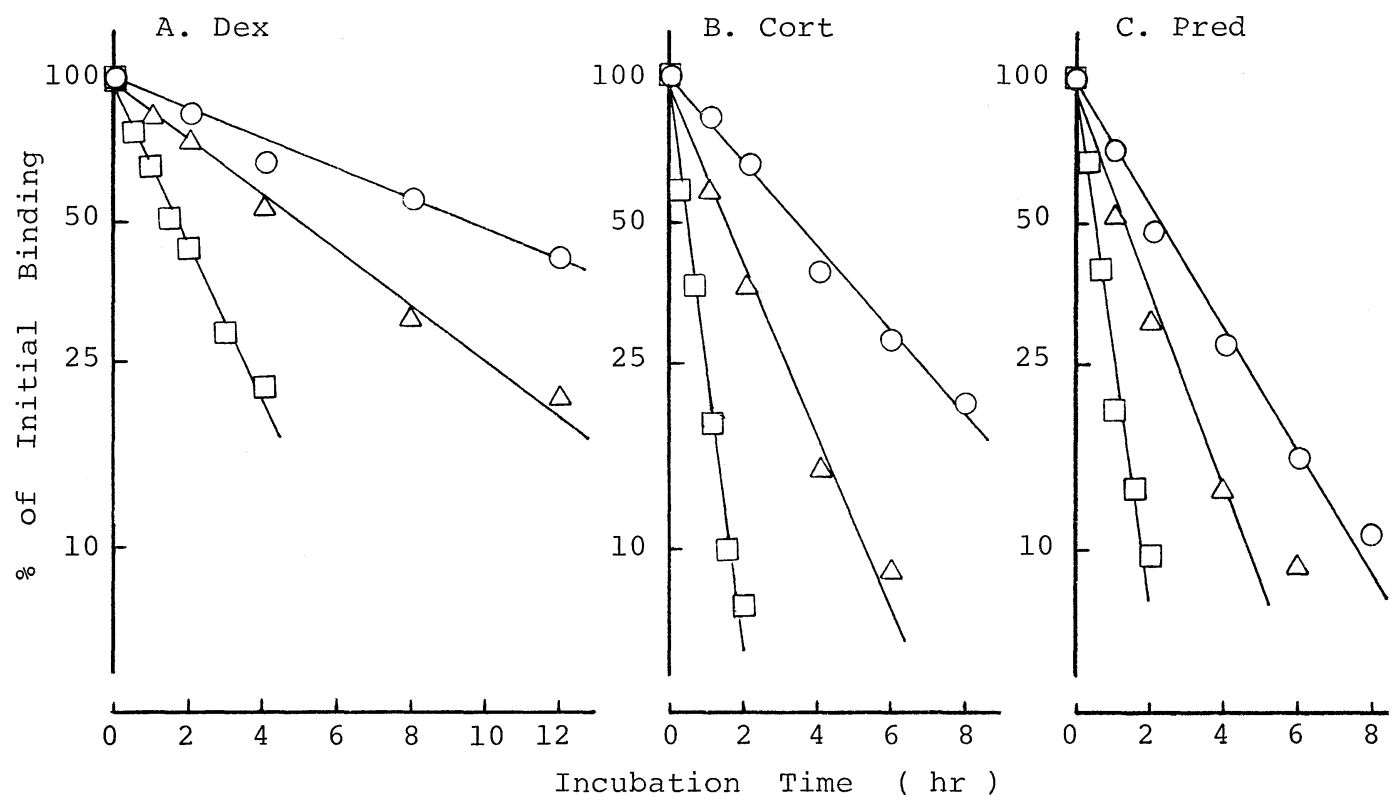

Fig. 5. Effect of temperature on the dissociation kinetics of ligands in the PPR labeled with ${ }^{3} \mathrm{H}$-Dex, ${ }^{3} \mathrm{H}$-Cort and ${ }^{3} \mathrm{H}$-Pred.

The PPR was labeled with $5 \mathrm{nM}$ of ${ }^{3} \mathrm{H}$-Dex, ${ }^{3} \mathrm{H}$-Cort and ${ }^{3} \mathrm{H}$-Pred at $0^{\circ} \mathrm{C}$ for $16 \mathrm{~h}$ and treated with DCC as described in 'Materials and Methods.' The labeled PPR was incubated at $0(\bigcirc), 10(\triangle)$ and $20^{\circ} \mathrm{C}(\square)$ in the presence of $5 \mu \mathrm{M}$ of unlabeled Dex. At various time intervals after the start of incubation, aliquots were taken and the concentration of bound ${ }^{3} \mathrm{H}$-ligands was determined by the DCC procedure. Results are expressed as \% of unincubated control and plotted semilogarithmically against incubation time. The radioactivity of the unincubated control was $10,400,7,600$ and $8,800 \mathrm{dpm}$ per $0.1 \mathrm{ml}$ for ${ }^{3} \mathrm{H}$-Dex (Fig. 5-A), ${ }^{3} \mathrm{H}$ Cort (Fig. 5-B) and ${ }^{3} \mathrm{H}$-Pred (Fig. 5-C), respectively. The protein concentration in the incubation mixtures was approximately $4.7 \mathrm{mg}$ per $\mathrm{ml}$. The rate constant of dissociation $\left(\mathrm{k}_{2}\right)$ was calculated from the slopes of lines in the figure.

Table 2. Kinetic constants for glucocorticoid binding in the PPR.

\begin{tabular}{lccccc}
\hline \hline Ligand & Temp. $\left({ }^{\circ} \mathrm{C}\right)$ & $\mathrm{k}_{1}\left(10^{6} \mathrm{M}^{-1} \cdot \mathrm{min}^{-1}\right)$ & $\mathrm{k}_{2}\left(10^{-3} \min ^{-1}\right)$ & $\mathrm{K}_{\mathrm{a}}\left(\mathrm{k}_{1} / \mathrm{k}_{2}, 10^{9} \mathrm{M}^{-1}\right)$ & $\mathrm{K}_{\mathrm{d}}\left(10^{-9} \mathrm{M}\right)$ \\
\hline${ }^{3} \mathrm{H}-\mathrm{Dex}$ & 0 & 1.68 & 1.21 & 1.39 & 0.72 \\
& 10 & 3.01 & 2.41 & 1.25 & 0.80 \\
& 20 & 6.63 & 7.22 & 0.92 & 1.09 \\
${ }^{3} \mathrm{H}$-Cort & 0 & 2.26 & 3.40 & 0.66 & 1.50 \\
& 10 & 3.40 & 7.40 & 0.46 & 2.17 \\
& 20 & 4.90 & 23.10 & 0.21 & 8.71 \\
${ }^{3} \mathrm{H}-$ Pred & 0 & 0.58 & 9.70 & 0.12 & 9.10 \\
& 10 & 0.96 & 9.24 & 0.10 & 13.68 \\
& 20 & 1.30 & 17.78 & 0.07 & \\
\hline
\end{tabular}

All calculations were based on the assumption that steroid binding to glucocorticoid receptor involves a simple and reversible bimolecular reaction (Rousseau, 1975, Yeakley et al., 1980). The rate constants for association $\left(\mathrm{k}_{1}\right)$ and dissociation $\left(\mathrm{k}_{2}\right)$ were obtained from the data depicted in Figs. 4 and 5, respectively. 
When the ratio of the rate constants of association and dissociation was used to calculate the equilibrium association constants for binding of the 3 ligands, the values obtained were quite similar to those obtained by the method of Scatchard (1949)

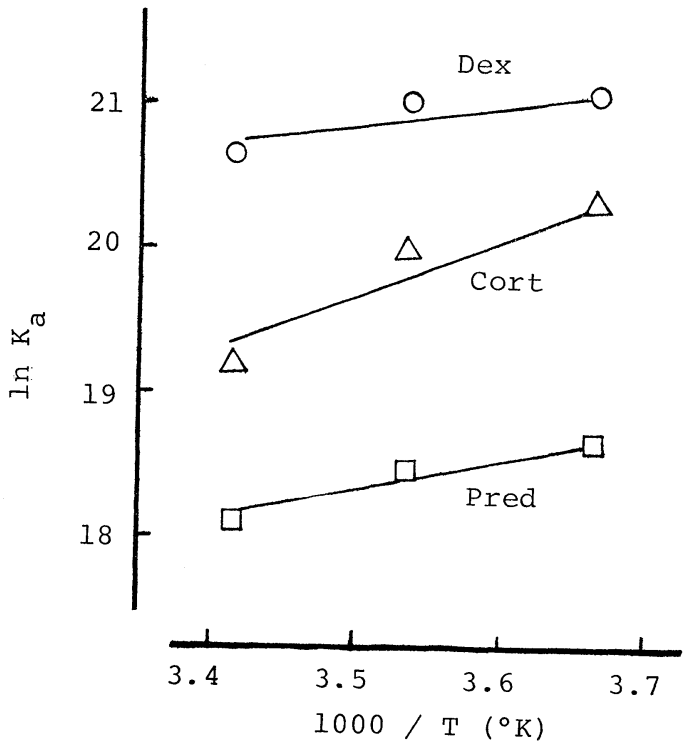

Fig. 6. Van't Hoff plots of glococorticoid binding in the PPR.

The $\mathrm{K}_{\mathrm{a}}$ for the binding of ${ }^{3} \mathrm{H}$-glucocorticoids in the PPR is calculated as the ratio of the rate constants of association and dissociation $\left(\mathrm{k}_{1} / \mathrm{k}_{2}\right.$, Table 2).
(Fig. 1-B, 'equilibrium condition'). $\mathrm{K}_{\mathrm{a}}$ of ${ }^{3} \mathrm{H}$ Dex binding was less affected by changing the temperature than those of the other 2 ligands.

\section{Thermodynamic parameters}

The Van't Hoff plots of the association constants for 3 glucocorticoids in the PPR (Table 2) are shown in Fig. 6. From the slopes of the plots, changes in the enthalpy $\left(\Delta \mathrm{H}^{\circ}\right)$ for the binding of 3 ligands were calculated (Table 3). Using these values $\left(\Delta \mathrm{H}^{\circ}\right)$ and $\Delta \mathrm{G}^{\circ}$ calculated from the apparent $\mathrm{K}_{\mathrm{a}}$ (Table 2), changes in entropy $\left(\Delta \mathrm{S}^{\circ}\right)$ were also calculated (Table 3 ). At all temperatures examined, the binding of ${ }^{3} \mathrm{H}$-Cort was accompanied by a small $\Delta \mathrm{S}^{\circ}$, while the binding reaction of ${ }^{3} \mathrm{H}$-Dex and ${ }^{3} \mathrm{H}$-Pred

Table 3. Thermodynamic parameters of glucocorticoid binding in the PPR.

\begin{tabular}{|c|c|c|c|}
\hline Ligand $\frac{\ln \mathrm{K}_{\mathrm{a}}}{0^{\circ} \mathrm{C}^{*}}$ & $\begin{array}{c}\Delta \mathrm{G}^{\circ}, 0^{\circ} \mathrm{C} \\
\left.\mathrm{kcal} \cdot \mathrm{mol}^{-1}\right)(\end{array}$ & $\underset{\mathrm{al} \cdot \mathrm{mol}^{-1}}{\Delta \mathrm{H}^{\circ}}$ & $\begin{array}{r}\Delta \mathrm{S}^{\circ}, 0^{\circ} \mathrm{C} \\
\left(\mathrm{cal} \cdot \mathrm{mol}^{-1}\right. \\
\left.\cdot \mathrm{K}^{-1}\right)\end{array}$ \\
\hline H-Dex 21.05 & -11.42 & -3.0 & 30.84 \\
\hline & & & \\
\hline A-Pred 18.63 & & -3.5 & 24.21 \\
\hline \multicolumn{4}{|c|}{$\begin{array}{l}\text { * calculated from the kinetic data }\left(\mathrm{k}_{1} / \mathrm{k}_{2}\right) \text { in } \\
\text { Table } 2 \text {. } \\
\Delta \mathrm{H}^{\circ} \text { was obtained from the slopes of the } \\
\text { Van't Hoff plots (Fig. } 6 \text { ). } \Delta \mathrm{G}^{\circ}, 0^{\circ} \mathrm{C}=-\mathrm{RT} \cdot \mathrm{ln} \\
\left.\mathrm{K}_{\mathrm{a}}, 0^{\circ} \mathrm{C} \text { (Eliard and Rousseau, } 1984\right) . \Delta \mathrm{S}^{\circ}, 0^{\circ} \mathrm{C} \\
\text { was obtained by the equation, } \Delta \mathrm{G}^{\circ}, 0^{\circ} \mathrm{C}=\Delta \mathrm{H}^{\circ} \\
-273 \cdot \Delta \mathrm{S}^{\circ}, 0^{\circ} \mathrm{C} \text {. }\end{array}$} \\
\hline
\end{tabular}

Table 4. Thermodynamic parameters for association and dissociation of ${ }^{3} \mathrm{H}$-Dex, ${ }^{3} \mathrm{H}$-Cort and ${ }^{3} \mathrm{H}$-Pred in the PPR.

\begin{tabular}{|c|c|c|c|c|c|c|}
\hline \multirow[b]{2}{*}{ Ligand } & \multicolumn{3}{|c|}{ Association } & \multicolumn{3}{|c|}{ Dissociation } \\
\hline & $\begin{array}{c}\Delta \mathrm{H}^{\neq} \\
\left(\mathrm{kcal} \cdot \mathrm{mol}^{-1}\right)\end{array}$ & $\begin{array}{c}\Delta \mathrm{S}^{\mp}, 10^{\circ} \mathrm{C} \\
\left(\mathrm{cal} \cdot \mathrm{mol}^{-1} \cdot \mathrm{K}^{-1}\right)\end{array}$ & $\begin{array}{l}\Delta \mathrm{G}^{\neq}, 10^{\circ} \mathrm{C} \\
\left(\mathrm{kcal} \cdot \mathrm{mol}^{-1}\right)\end{array}$ & $\begin{array}{c}\Delta \mathrm{H}^{\neq} \\
\left(\mathrm{kcal} \cdot \mathrm{mol}^{-1}\right)\end{array}$ & $\begin{array}{c}\Delta \mathrm{S}^{\neq}, 10^{\circ} \mathrm{C} \\
\left(\mathrm{cal} \cdot \mathrm{mol}^{-1} \cdot \mathrm{K}^{-1}\right)\end{array}$ & $\begin{array}{c}\Delta \mathrm{G}^{+}, 10^{\circ} \mathrm{C} \\
\left(\mathrm{kcal} \cdot \mathrm{mol}^{-1}\right)\end{array}$ \\
\hline${ }^{3} \mathrm{H}-\mathrm{Dex}$ & 9.8 & -2.1 & 10.4 & 12.6 & -33.9 & 22.3 \\
\hline${ }^{3} \mathrm{H}$-Cort & 6.3 & -14.4 & 10.4 & 18.5 & -10.1 & 21.4 \\
\hline${ }^{3} \mathrm{H}$-Pred & 6.3 & -16.7 & 11.0 & 12.8 & -30.1 & 21.3 \\
\hline
\end{tabular}

The interpretation of the rate constant of elementary reaction process by the transition-state theory was described in detail previously (Satoh et al., 1984). When the plot of $\ln \mathrm{k} v s .1 / \mathrm{T}$ was used as an Arrhenius plot (Fig. 7), the values for $\Delta \mathrm{H}^{\neq}$and $\Delta \mathrm{S}^{\neq}$were calculated from the slope and intercept of the line. $\Delta \mathrm{G}^{\neq}, 10^{\circ} \mathrm{C}$ was obtained by the equation, $\Delta \mathrm{G}^{\neq}, 10^{\circ} \mathrm{C}=\Delta \mathrm{H}^{\neq}$ $-283 \times \Delta \mathrm{S}^{\mp}, 10^{\circ} \mathrm{C}$. 
was driven by more than 2.5 times higher $\Delta \mathrm{S}^{\circ}$. Differences in the $\Delta \mathrm{S}^{\circ}$ in ligands were further confirmed by calculating the enthalpy change $\left(\Delta \mathrm{H}^{\circ}\right)$ using the activation energies of association and dissociation reactions, which were estimated from the slopes of Arrhenius plots of the rate constants (Fig. 7). These values are tabulated in Table 4.

\section{Discussion}

Elucidation of the relationship between the binding parameters and the biological potencies of various glucocorticoids seems to be physiologically meaningful. Binding affinities and the number of binding sites of various glucocorticoids in target tissues have been estimated by a number of investigators but, as pointed out previously, those values obtained under the incubation conditions where the ligands received transformations during the period of the incubation are not reliable (Ichii et al., 1983). To obtain reliable binding parameters, it is necessary to separate the receptor from the metabolic activity of ligands in the cytosol. For this purpose, we choose a method in which the receptor is charged with ${ }^{3} \mathrm{H}$-Dex prior to the start of purification, since a marked protective effect of ligand against denaturation on the glucocorticoid receptor has been reported (Rafestin-Oblin et al., 1977, Schmid et al., 1976) and the radioactivity is a good measure of the localization of the receptor during the separation procedures. In the present study, more than 100 -fold purification was achieved within a relatively short

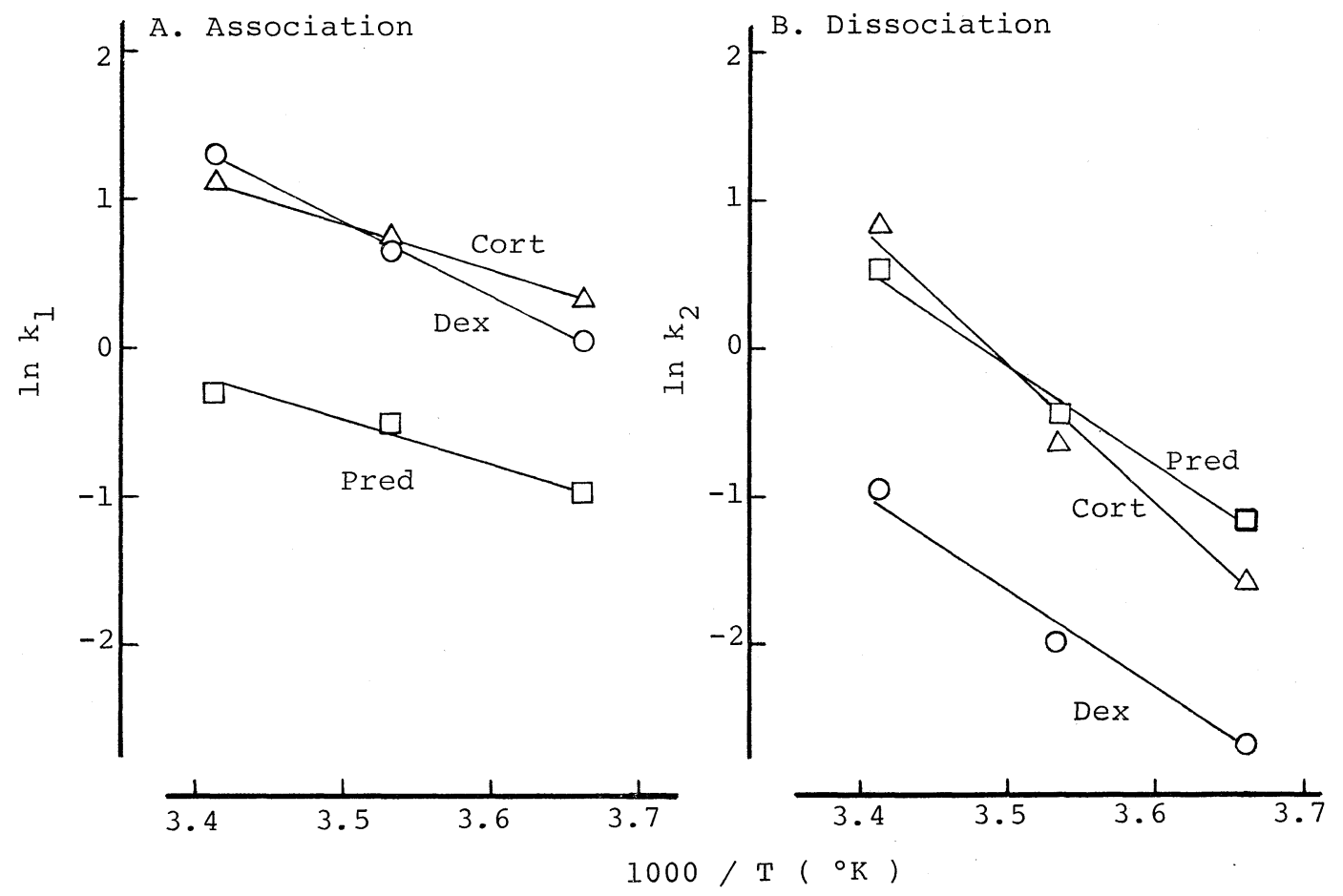

Fig. 7. Arrhenius plots of glucocorticoid binding in the PPR.

The rate constants $\left(\mathrm{k}_{1}\right.$ and $\left.\mathrm{k}_{2}\right)$ were measured at 0,10 and $20^{\circ} \mathrm{C}$ as described in the legend to Table 2 and depicted by Arrhenius plots. 
period and the preparation obtained does not exhibit any measurable activity of the biotransformation of ligands, even in the most susceptible ligand, Cort. Furthermore the preparation can be stored at $-20^{\circ} \mathrm{C}$ in the presence of Mo, DTT, BSA and glycerol without any loss of binding activity for at least 2 months. The bound ${ }^{3} \mathrm{H}-\mathrm{Dex}$ in the preparation is easily removed by treating the preparation with PHMB without significant loss of the binding capacity (Banerji and Kalimi, 1981) and reassociation takes place when the incubation mixture includes $10 \mathrm{mM}$ DTT. The reassociated preparation still retains the ability to bind to DNAcellulose after brief heating and this seems to indicate that the preparation is functionally intact (Table 1, Schmidt and Litwack, 1982). Using this partially purified preparation, we estimated binding parameters for Dex, Cort and Pred. Depletion of the cytoplasmic receptor by administration of glucocorticoids in the rat liver was well correlated with the ability to induce tyrosine aminotransferase (Izawa et al., 1982) and the relative potencies depleting the cytoplasmic receptor are 50:5:1 for Dex, Pred and Cort, respectively (Ichii, 1981). The $\mathrm{K}_{\mathrm{d}}$ 's obtained by the method of Scatchard (1949) in the present study are $\sim 0.9, \sim 3$ and $\sim 6$ $\mathrm{nM}$ for Dex, Cort and Pred, respectively (Fig. 1-B). Therefore, the binding affinity is not a reliable measure of the biological potency of glucocorticoids. It was suggested previously that structure-related differences in nuclear binding ability, stability in the nuclei of the receptor complexes and metabolic susceptibility of the ligands may contribute to the biopotency of glucocorticoids (Ichii et al., 1983, 1984). The fact that the binding affinity of Cort is twice as high as that of Pred but the biopotency of Cort is $1 / 5$ of Pred may show that the rate of metabolic transformation in target tissues is one of the major factors which determine the biopotency of glucocorticoids. Relative binding affinity of various steroids to gluco- corticoid receptor estimated by competition experiments in the purified preparation is different from that estimated in the crude cytosol (Fig. 3). Significant inhibition by progesterone and cortexolone is observed only in the PPR and this also may be explained by the metabolic transformation of these steroids during the incubation period. From the results obtained in the experiments on the kinetics of glucocorticoid binding to the PPR (Table 2, Figs. 4 and 5), differences in the binding characteristics of Dex, Cort and Pred became evident. The rates of association of these 3 glucocorticoids are relatively high when compared with the rates of dissociation, and the effect of temperature is more pronounced in the rate of dissociation. Therefore, the dissociation rate is one of the factors which determine the binding affinity of ligands. $\mathrm{K}_{\mathrm{d}}$ 's estimated in this 'transition condition' are almost identical to those observed in the 'equilibrium condition' described above. Thermodynamic parameters of glucocorticoid binding in the PPR estimated from the slopes of Van't Hoff plots (Fig. 6) clearly indicate that the binding reaction proceeds at a higher rate in the order of Dex $>$ Cort $>$ Pred (Table 3). The binding of synthetic glucocorticoids is driven mainly by entropy change $\left(\Delta \mathrm{S}^{\circ}\right)$ rather than enthalpy change $\left(\Delta \mathrm{H}^{\circ}\right)$ and intrinsic differences in the binding characteristics between natural and synthetic glucocorticoids are suggested. The differences in the thermodynamic parameters are confirmed when the activation energies of binding reactions $\left(\Delta \mathrm{H}^{\ddagger}\right)$ are estimated by Arrhenius plots of rate constants (Fig. 7 and Table 4). Several studies on the thermodynamic properties of interaction of steroid hormones with receptors have been reported and an almost similar range of thermodynamic parameters have been observed (Chang-ren et al., 1983, Eliard and Rousseau, 1984, Hansen et al., 1976, Koblinsky et al., 1972, Pratt et al., 1975, Satoh et al., 1984, Wolff et al., 1978, Yeakley et al., 1980). 
In summary, the binding affinity of glucocorticoids to the receptor in vitro varies with ligands, higher in the order of Dex $>$ Cort $>$ Pred. The fact that the biopotency of these 3 glucocorticoids is higher in the order of Dex $>$ Pred $>$ Cort may imply that the biopotency of glucocorticoids in vivo is not related to the binding affinity to the receptor estimated in vitro.

\section{Acknowledgement}

This work was supported in part by grantsin-aid for Scientific and Co-operative research from the Ministry of Education, Science and Culture, Japan.

\section{References}

Alberts, B. and G. Herrick (1971). DNA-cellulose chromatography. Meth. Enzymol. XXI Part D, 198-217.

Banerji, A. and M. Kalimi (1981). Development of an $\left[{ }^{3} \mathrm{H}\right]$ glucocorticoid exchange assay in rat liver cytosol. Steroids 37, 409-421.

Baxter, J. D. and G. M. Tomkins (1971). Specific cytoplasmic glucocorticoid hormone receptors in hepatoma tissue culture cells. Proc. Natl. Acad. Sci. USA 68, 923-937.

Burton, K. (1968). Determination of DNA concentration with diphenylamine. Meth. Enzymol. XII Part B, 163-166.

Chang-ren, Y., D. H. Seeley, J. Mester, A. Wolfson and E. E. Baulieu (1983). Temperature dependence of the dissociation rate constant for the non-activated (molybdate-stabilized) and activated progesterone receptor-hormone complexes from the chick oviduct. Biochim. Biophys. Acta. 755, 428-433.

Eliard, P. H. and G. G. Rousseau (1984). Thermodynamics of steroid binding to the human glucocorticoid receptor. Biochem. J. 218, 395404.

Govindan, M. V. and C. E. Sekeris (1978). Purification of two dexamethasone-binding proteins from rat-liver cytosol. Eur. J. Biochem. 89, 95-104.

Hansen, P. E., A. Johnson, T. Schrader and B. W. O'Malley (1976). Kinetics of progesterone binding to the chick oviduct receptor protein. J. Steroid Biochem. 7, 723-732.

Ichii, S. (1981). Depletion and replenishment of glucocorticoid receptor in cytosols of rat tissues after administration of various glucocorticoids. Endocrinol. Japon. 28, 293-304.

Ichii, S., N. Noguchi and A. Yoshida (1983). Biopotency and nuclear binding in glucocorticoids. Endocrinol. Japon. 30, 179-188.

Ichii, S., Y. Satoh, M. Izawa and K. Iwasaki (1984). Stability of receptor complexes in the rat liver bound to glucocorticoids of different biopotencies. Endocrinol. Japon. 31, 583-594.

Izawa, M., A. Yoshida and S. Ichii (1982). Dynamics of glucocorticoid receptor and induction of tyrosine aminotransferase in rat liver. Endocrinol. Japon. 29, 209-218.

Izawa, M., Y. Satoh, K. Iwasaki and S. Ichii (1984). Glucocorticoid receptor in the rat uterus. Endocrinol. Japon. 31, 491-500.

Jones, T. R. and P. A. Bell (1982). Glucocorticoidreceptor interactions: discrimination between glucocorticoid agonists and antagonists by means of receptor-binding kinetics. Biochem. J. 204, 721-729.

Koblinsky, Y., M. Beato, M. Kalimi and P. Feigelson (1972). Glucocorticoid-binding proteins of rat liver cytosol. J. Biol. Chem. 247, 7897-7904.

Lamontagne, N., L. Mercier, M. Pons, E. B. Thompson and S.S. Simons (1984). Glucocorticoid versus antiglucocorticoid activity: can a single functional group modification of glucocorticoid steroids always convey antiglucocorticoid activity? Endocrinology 114, 22522263.

Lowry, O. H., N. J. Rosebrough, A. L. Farr and R. J. Randall (1951). Protein measurement with the folin phenol reagent. J. Biol. Chem. 193, 265-275.

Miyabe, S. and R. W. Harrison (1983). In vivo activation and nuclear binding of AtT-20 mouse pituitary tumor cell glucocorticoid receptor. Endocrinology 112, 2174-2180.

Pratt, W. B., J. L. Kaine and D. V. Pratt (1975). The kinetics of glucocorticoid binding to the soluble specific binding protein of mouse fibroblasts. J. Biol. Chem. 250, 4584-4591.

Rafestin-Oblin, M-E., A. Michaud, M. Claire and P. Corvol (1977). Dramatic protective effect of ligand against thermal degradation on mineralo- and glucocorticoid receptor in rat kidney. J. Steroid Biochem. 8, 19-23. 
Rousseau, G. G., J. D. Baxter and G. M. Tomkins (1972). Glucocorticoid receptors: relation between steroid binding and biological effects. J. Mol. Biol. 67, 99-115.

Rousseau, G. G. (1975). Interaction of steroids with hepatoma cells: molecular mechanism of glucocorticoid hormone action. J. Steroid Biochem. 6, 75-89.

Samuels, H. and G. M. Tomkins (1970). Relation of steroid structure to enzyme induction in hepatoma tissue culture cells. J. Mol. Biol. 52, 57-74.

Satoh, Y., M. Izawa and S. Ichii (1984). Stability of receptor complexes in the rat ventral prostate and seminal vesicle bound to androgens: thermodynamic study. Endocrinol. Japon. 31, 777-791.

Scatchard, G. (1949). The attraction of protein for small molecules and ions. Ann. N. Y. Acad.
Sci. 51, 660-672.

Schmid, H., H. Grote and C. E. Sekeris (1976). Stabilization and characterization of the dexamethasone-binding proteins in rat liver cytosol. Mol. Cell. Endocrinol. 5, 223-241.

Schmidt, T. J. and G. Litwack (1982). Activation of the glucocorticoid-receptor complex. Physiol. Rev. 62, 1131-1192.

Wolff, M. E., J. D. Baxter, P. A. Kollman, D. L. Lee, I. D. Kuntz, E. Bloom, D. T. Matulich and J. Morris (1978). Nature of steroid-glucocorticoid receptor interactions: thermodynamic analysis of the binding reaction. Biochemistry 17, 3201-3208.

Yeakley, J. M., K. Balasubramanian and R.W. Harrison (1980). Comparison of glucocorticoidreceptor binding kinetics with predictions from a bimolecular model. J. Biol. Chem. 255, 4182 -4188 . 